\title{
Developing A Conceptual Framework for Science Teaching at Colleges of Education in Ghana
}

\author{
A. M. Naah, M. Owusu, V. Osei-Himah, F. Owusu Ansah, T. K. Mensah, T. Y. Amuda, R. Osei Yaw, \\ J. A. Samari, A. Y. K. Agyemang, L. Opoku Acheampong, and O. K. Kwaah
}

\section{ABSTRACT}

This paper looks at Science taught in Ghana generally. It defines Science and science education fundamentally, as the methodical observation, conception, analysis, and exhibition of patterns to understand what exist in the physical universe which is evidence-based and their interactions with each other. The understanding of these processes keeps changing as new relationships and explanations emerge. The motion and interactivity with materials employed by the pedagogies become key elements for creating exciting, dynamic and captivating experiences that motivate students to learn and pursue a science course with a greater sense of purpose. Science education is the teaching and learning of science to nonscientists, such as school children, college students, or adults within the general public. The field of science education includes work in science content, science process, some social science, and some teaching pedagogy. However, the employ of inappropriate teaching methodologies is one of the factors that contribute to the low participation and performance of students in science. Little effort is made to relate the concepts learnt and the examples/illustrations used to real life, especially within the context of the students' own lives and environment. This article attempts to proffer a concise definition to merge the ideas from some scholars for a better understanding of science; meaning of Science Education; relevance of the study of science (or science education); problems of science teaching in Ghana and the effects and propounds a challenging model for implementation for effective science teaching in Colleges of Education in Ghana.

Keywords: Science education, science teaching.
Published Online: November 13, 2021

ISSN: $2736-4534$

DOI : $10.24018 /$ ejedu.2021.2.6.190

A. M. Naah*

Department of Teacher Education, Kwame Nkrumah University of Science and Technology, Kumasi, Ghana.

(e-mail: annanaah2002@yahoo.com) M. Owusu

Department of Teacher Education, Kwame Nkrumah University of Science and Technology, Kumasi, Ghana.

(e-mail:

stmichaelacademy69@yahoo.com)

V. Osei-Himah

Department of Teacher Education,

Kwame Nkrumah University of Science and Technology, Kumasi, Ghana.

(e-mail: oseihimah@gmail.com)

F. Owusu Ansah

Department of Teacher Education, Kwame Nkrumah University of Science and Technology, Kumasi, Ghana.

(e-mail:

sirfrankowusuansah@gmail.com)

T. K. Mensah

Department of Teacher Education, Kwame Nkrumah University of Science and Technology, Kumasi, Ghana.

(e-mail: timothy.mensah@ucc.edu.gh)

T. Y. Amuda

Department of Teacher Education, Kwame Nkrumah University of Science and Technology, Kumasi, Ghana.

(e-mail: aytahiru2018@gmail.com)

R. Osei Yaw

Department of Teacher Education, Kwame Nkrumah University of Science and Technology, Kumasi, Ghana.

(e-mail: roymens94@gmail.com)

J. A. Samari

Department of Teacher Education, Kwame Nkrumah University of Science and Technology, Kumasi, Ghana.

(e-mail: ayeljon@gmail.com)

A. Y. K. Agyemang

Department of Teacher Education, Kwame Nkrumah University of Science and Technology, Kumasi, Ghana.

(e-mail:

akyagyemang@joscobechem.edu.gh)

L. Opoku Acheampong

Department of Teacher Education, Kwame Nkrumah University of Science and Technology, Kumasi, Ghana.

(e-mail: 1ydiachie73@yahoo.com)

O. K. Kwaah

Department of Teacher Education, Kwame Nkrumah University of Science and Technology, Kumasi, Ghana.

(e-mail: kak1124@yahoo.com)

Vol 2 Issue 6 | November 2021 


\section{INTRODUCTION}

Understanding concepts in the field of science, in general as a learner, has been a major problem for most students especially at the Junior and Senior high school levels in Ghana. This is manifested by a large number of them failing in the core Integrated Science subject in the Basic Education Certificate Examination (BECE) and West Africa Senior School Certificate Examination (WASSCE) organized by the West Africa Examination Council, year in and year out. Science may be simple but difficult if not well directed and delivered by the facilitator.

Science, by and large, is the methodical observation, conception, analysis, and exhibiting of patterns to understand what exist in the physical universe, which is evidence-based and their interactions with each other (Mickens \& Patterson, 2016; Demirci-Guler, 2013; Aka, Guven \& Aydoğdu, 2010; Arabacioglu \& Unver, 2016). The understanding of these processes keeps changing as new relationships and explanations emerge (Punia, Jizah, Adzliana, \&Kamisah, 2012). These changes as they arise lend credence to new directions to science.

Holistically, science can be said to encompass the understanding of various phenomena, the exploration of ideas and their relationships, explanations and conclusion that exist. The probing of these ideas leads to the development or proposal of new theories, skills and scientific knowledge through research, experimentation, laboratory work and clinical. Science education is a discipline that is concerned with the teaching and learning of science formally and informally. Technology and Engineering are by-products and applications of science education because they are based on the principles of science and its education. Overall, Science education is a vital and necessary vehicle for improving vital skills for problem solving, critical thinking and creativity.

Science education aims to increase people's understanding of science and the construction of scientific knowledge as well as to promote scientific literacy and responsible citizenship, and also helps peoples to define their attitude ( $\mathrm{Su}$, 2016; Živkovic, 2016; Wood, 2006). However, there are constraints in taking students through science courses in most parts of the world. These include lack of qualified teachers, high school fees at the university level, students shying away from science related courses, teachers not being well vexed in the art of teaching the sciences, abstract teaching, lack of science equipment and facilities (Su, 2016; Živkovic, 2016; Wood, 2006). Other limitations include overblown syllabus, textbooks whose contents do not match with the curriculum, the employ and usage of inappropriate techniques of teaching, the misunderstanding of some concepts by some teachers, and wrong application of concepts (Punia et al., 2012). Additionally, in Ghana there is currently the absence of General or Integrated science as a programme of study in the universities in Ghana. It has been asserted by many experience scholars that the best method to teach science is through.

a) Experiential learning: Making the learners go through various science concepts physically has the opportunity to consider what is working or failing and to think about ways to improve them (Henry, 2017).

b) Availability of basic equipment: Minimum equipment is required for learners to manipulate and employ to understand various science concepts (Mishra, 2013).

c) Experience Teaching: Classroom teachers must be very experienced to make learners understand and appreciate the concepts being passed on to them (Punia et al., 2012).

Thus, this article attempts to dwell on the relevance of the teaching and learning of science (or science education); problems of science teaching in Ghana and the effects thereof and propose a model for implementation for science teaching in Colleges of Education in Ghana.

\section{Relevance of Science EducAtion}

One of the most coveted programmes in school in terms of relevance to the lives of learners is Science Education. Throughout their various programmes of study, students of science are trained using special pedagogies to get them involved in the various key or fundamental processes of science. These develop problem-solving skills for the learners and their life-long wellbeing. The motion and interactivity with materials employed by the pedagogies become key elements for creating exciting, dynamic, and captivating experiences that motivate students to learn and pursue the science course with a greater sense of purpose (University of Texas Arlington, 2017). In other words, Science Education benefits learners by not only affording problem-solving skills that include technological literacy and critical thinking but also motivation, all of which are necessary for them to succeed in school and beyond. But this is just but one of the ways that Science Education is relevant to the life of the learner. Factually, it fosters more than just problem-solving techniques. Indeed, it brings out a variety of the learner's core competencies, which are a fundamental body of other skills as well as knowledge that shape a person and which instructors at all levels feel obligated to inculcate in learners. The ability to communicate well is, for instance, a necessary skill for evaluating and disseminating scientific knowledge. Other core skills that are indeed a connected body of abilities arising from Science Education include critical thinking and problem solving; creativity and innovation; communication and collaboration; a sense of cultural identity and global citizenship; personal development and leadership, as well as digital literacy (MOE, 2019).

Again, Science Education is relevant to learners in terms of how it drives their increasing understanding of science, the construction of knowledge as well as the promotion of scientific literacy and responsible citizenship. This means learners are cognitively strengthened and ready to better understand and construct knowledge and hence solve societal problems more easily using scientific processes. Inherently, this generates in learners an interest in further studies of science and increases positive attitudes towards scientific issues in the society. Furthermore, science education offers graduates a powerful platform for building confidence, authoritatively communicating scientific findings and information, and generally making a sense of the world around. In this way the world becomes increasingly shaped by science and technology because the enquiry skills people acquire through Science Education not only make them better able to ask probing questions but also equip them as good collectors and analyzers of information, which they ably apply to solve everyday problems. In other words, when 
people acquire scientific skills, they are better placed to explore the world around them and tackle pertinent local as well as global challenging issues.

Traditionally, experts in Science Education occasionally share some science content and processes with individuals, who may not necessarily be members of the scientific community. Regardless of whether such persons are lettered, illiterate farmers, market women or a community member group some may all the same be smart enough to take advantage of such encounters and make a difference in their lives. This is particularly so when the science content is laced with minds-on and hands-on activities. For example, a graduate in Physics who possesses some knowledge of electronics is for instance well positioned to take full advantage of a content sharing forum in Electronics to become a full-fledged standalone electronics technician. Consequently, people like such a graduate could become entrepreneurs and in no small way contribute to the economic development of a country (Agbidye, Agbidye \& Aboho, 2014).

Finally, it is through Science Education, with its systematic methodological evidence, that the right pursuit and application of knowledge, which advances a better understanding of both the natural and social world is achieved. The learner is equipped with new ways of thinking and investigating natural phenomena. This leads to new knowledge and the generation of solutions that promote education, increases the quality of life, and thus enhances the development of society and the world at large.

\section{Problems OF SCIENCE TEACHING IN GHANA AND THE EFFECTS}

One of the Ghana's developments rests on science and its application in the world of work and industry. Competent workers and citizenry in general need a sound understanding of science and mathematics (Anamuah-Mensah, 2004). A strong science and technology base therefore constitutes the currency for social and economic transformation of nations (Anamuah-Mensah, 2004). Teachers are responsible that citizens acquire this knowledge and are expected to teach inquiry science to the young ones. Science education is needed in Ghana to produce the necessary human resource and skilled labour force to manage our local industries.

Ghana is the first independent sub-Saharan African country, aside South Africa, to begin a comprehensive measure to promote science education and the use of science in industrial and social development (Apter, 2008; Godek, 2004). Even though on paper the curriculum for science education appears to be perfect, that is not what it is. It has been seen that, the rate of scientific literacy among the youth who constitute about 44 percent of the Ghanaian population is low and that of the adult is even lower (Barke, Nyarko \& Klecha, 2011). Several problems have been identified that includes lack of well-equipped laboratories for practical, lack of qualified teachers, textbooks not matched with curriculum as some of the problems of science teaching in Ghana.

First of all, inappropriate teaching methods have been a major problem militating against the teaching of science in Ghana. O'Connor (2002) identified inappropriate teaching methods as one of the factors that contribute to the low participation and performance of students in science. He asserted that the teaching methods used were not practical enough and that teachers make little effort to relate the concepts learnt and provide examples/illustrations used in real life, especially within the context of the students' own lives and environment. This has a negative effect on students' interest and motivation to study science, mathematics, and technology (SMT) subjects. The most used teaching methodology at both basic and secondary levels is "lecturing" interspaced with some question-and-answer techniques. This is followed by the explanations of procedures of a concept and notes giving (O'Connor, 2002). Danso (2009) has indicated that teachers favor teacher-centered, knowledgebased teaching methods that leave little room for learners' participation.

Most teachers also teach the concepts of science without mostly following the processes of science. Azure (2015) reported that most of the processes of science (i.e., observing, hypothesizing, classifying, taking measurements, and reporting) were not often carried out during Integrated Science lessons. In addition, lack of teaching and learning resources also militate against science teaching. Little or no practical work is done due to shortage of equipment and consumables, and the development of a scientific way of thinking is abandoned in favor of the learning of nomenclature, definitions and stock standard procedures (O’Connor, 2002).

Furthermore, teacher education curriculum and teacher preparation are another cause of worry. Some science teachers do not provide clarity to the concepts of science because of their poor foundation in science. Brobbey, Baah and Ampon-Wireko (2020) asserted that the teaching and learning of science is affected negatively by inadequate and lack of skilled science teachers. It is evident that the teaching approaches employed by science teachers do not conform to the intentions of the planners of science curriculum in Ghana.

The biggest problem, in our opinion, is the absence of departments for Integrated Science in most universities in Ghana. Pre-service teachers who are churned out from these universities to teach in the basic, secondary and colleges of education are who are eventually trained in one of the elective science courses, end up teaching Integrated Science in these institutions. This cascades into and causes a chain reaction of poor teaching and learning of concepts in Integrated Science at the various levels in education.

To improve the teaching and learning of science, it is essential to focus on the preparation of teachers with adequate Pedagogical Content Knowledge (PCK) in the sciences and the needed attention should be given to institutions involved in pre-service teacher preparedness. Teacher education curriculum for pre-service teacher training at the various institutions should aim at producing competent and confident teachers who can excite and inspire all learners irrespective of gender, ethnic background, geographical location, or mental/physical ability (gender sensitive and inclusivity conscious teachers). The training of the pre-service teachers should equip them with a deep content knowledge in science with strong pedagogical skills to facilitate teaching and learning. To support the pre-service teachers' preparation for quality, competent and confident teachers for the basic education level, a model is hereby proposed for quality 
science teacher and learning in Colleges of Education in Ghana for implementation. The proposed model is illustrated in Fig. 1.

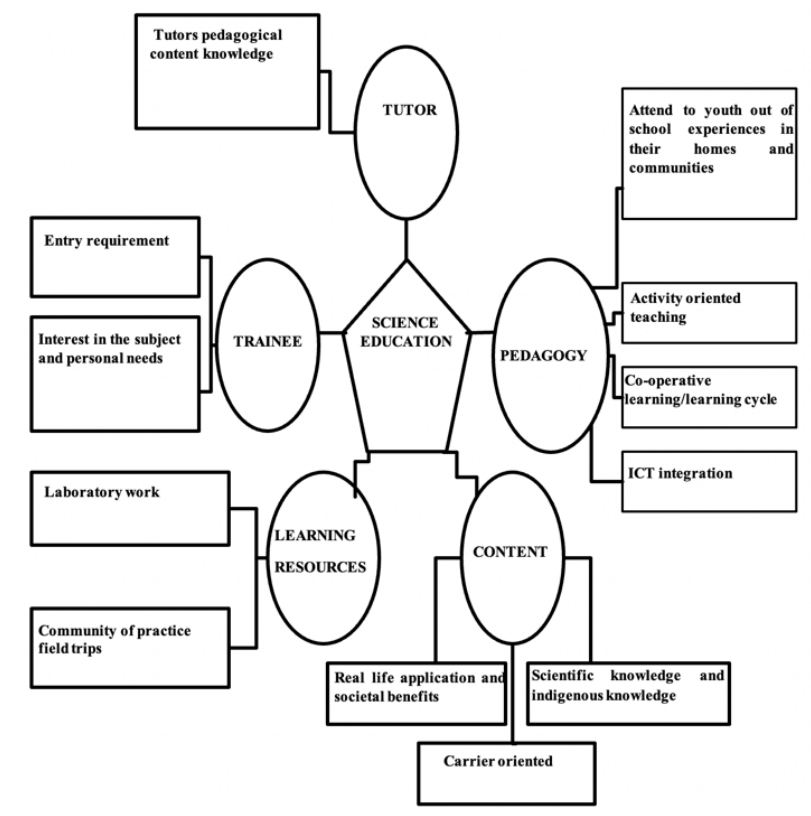

Fig. 1. Proposed model for science teaching for colleges of education in Ghana.

The proposed model for the Colleges of Education on the theoretical perspective in Science Education focuses on possible solutions for the deficiencies identified in the teaching and learning of science. They include The Tutor; The Trainee; Learning resources; the content; and Pedagogy.

\section{A. The Tutor}

The universities should train tutors with the requisite pedagogical content knowledge in integrated science as illustrated in the model. This implies the universities must create departments for Integrated Science education to specifically train teachers in Integrated Science teaching. Teaching styles, feedback to both learners and tutors, and assessment are all part of pedagogy. There is different pedagogical approach to learning in the classroom and one should consider the most effective one for content delivery based on student needs. Although Bloom (1984), and Lepper and Woolverton (2002) were working with younger students, it is common experience at the undergraduate level as well that many students can learn far more readily from a good tutor than from traditional lecture classes. Tutors should be equipped in all the different pedagogical approaches to learning with their relevant to content specific and theories of learning. Tutors should focus more on pedagogies such as constructivist, project-based, active learning collaboration, cooperation, problem-solving, active, and inquiry-based, the use of ICT tools so that trainees seek for and apply problembased learning to find solution to aid in their lesson delivery. Tutors should train pre-service teachers to use lively and engaging pedagogy with appropriate content and engage them in daily group activities for the pre-service teachers to be equipped with the usage and technique involved in the various pedagogies. Smith, Wood, Krauter and Knight (2011) found that an instructor's explanation after students had attempted, discussed, and revote on a challenging clicker question substantially enhanced student learning beyond either discussion or instructor explanation alone Tutors should take pre-service teachers through most of the topics and activities in the textbooks and curriculum that they are going to teach at the basic level. Tutors need to be armed with new and different pedagogies and strategies for teaching science.

\section{B. The Trainee}

The entry requirement of trainees and primarily their prerequisite knowledge and skills of basic science: It is meant to serve as a framework for admitting learners into the Colleges of Education for science programmes and for the prediction of high academic achievement of well-trained teachers for the basic level. The success of learners in educational programmes depends largely on the background and prerequisite knowledge they had in their previous education. Having a quality foundation in scientific concepts makes it easy to understand concepts at the next level in education and can be incredibly impactful. Admitting students into teacher preparation programmes for science should be based on the completion of the appropriate senior high school education in science, and with the evidence of exhibiting personal qualities expected to help impact knowledge to young ones. Having prior knowledge and an understanding of basic concepts is enormously significant in promoting good quality learning because these concepts form an important base for future learning. The science curriculum at the Colleges of Education is constructed as a continuum from basic courses towards more advanced courses. The preservice teachers' interest accepting the mandate to be trained and to also go out and impact the acquired knowledge is of great importance. Management in charge of admissions at Colleges of Education should strictly admit students who have the background in elective science and the interest of the trainee must also be considered during process.

\section{Learning Resources}

This aspect of the model looks at all aspects of accoutrements (facilities and equipment) that learners need to successfully undertake their programmes at the Colleges of Education. Typically, the use of a learning resource in the classroom is subject to a process of evaluation and approval at the school, local or national level. Evaluation criteria may include relevance to the curriculum and expectations for learning, social considerations, and age or developmental appropriateness. Learning resources are a key factor for effective implementation of the proposed model. Scientific literacy and the development of intellectual skills in science require the use of learning resources. Learning resources are some complex issues in the field of science education which include the availability of appropriate textbooks, classroom resources, and laboratory for the preparation and training of pre-service science teachers. Materials and any person (s) used for teaching learning purposes of achieving instructional content are referred to as learning resources. Pre-service teachers need to be introduced to diverse learning resources such as print and non-print materials, audio, visual, electronic media, software resources, human resources, and the science laboratory.

When learners are exposed to these learning resources, they make the teaching and learning process more attractive 
and interesting, encouraging active learning and the development of desirable values and attitudes of students. Knowledge gained, skills acquired, attitudes and values developed by pre-service teachers are easily impacted to the younger ones at the basic levels. Pre-service teachers should form social networks to interact with others in other institutes. In such a community of practice, pre-service teachers can perhaps jointly devise lessons in order to help each other understand and develop pedagogical content knowledge; and also, to reflect on their own teaching practice making them more knowledgeable, flexible and capable in their learning. A community of practice is an important tool for Colleges of Education as the communities serve as partnership and resource site can help drive strategy, solve problems quickly, and transfer best practices and skills regarding teaching and learning.

\section{The Content}

The training of pre-service teachers should equip them with a deep content knowledge in science. Greater emphasis should be on observation, conducting investigations, investigating the nature of science, description of natural phenomena, designing and planning of experiments, explanation based on evidence, and logical consistent arguments. The content of the college programmes should be designed to cater for models for inquiry geared towards critical thinking about science-related problems. The teaching and learning environment, immediate learner environment of interaction and the community should also be factored into the programme structure and curriculum overlay for the trainees. Most indigenous knowledge practices in the community have scientific meaning and implication for the teaching and learning of science. Integrating indigenous knowledge practices into the course structure will help preservice teachers relate concepts learnt to real life situations. Science exit in society and should contribute to the maintenance and aspirations of the people within the society. As a discipline it includes methods, thought processes, mind sets, values, concepts and experiences by which indigenous people understand, reflect and obtain empirical knowledge about the natural world. The course structure should be designed to include content that will help address social challenges directly related to science.

\section{E. Pedagogy}

Pedagogy as a study of teaching approaches describes how knowledge and skills are imparted in an educational context, and it considers the interactions that take place during teaching and learning and their effects on learners. It refers to how teachers teach in order to help students to build on their prior learning and a meaningful classroom interaction. A good, selected pedagogy is an enabler for students to learn effectively and develop high-order thinking skills. Pedagogy employs both learning theories and teaching styles and takes into consideration the context in which learning takes place, and the learners. In this phase of the model, modern ways of teaching and learning ICT integration which should be structured alongside lessons delivery. Cooperative/ collaborative learning, learning cycle, activity-oriented teaching and learning are various methods when employed can boost the confidence level of pre-service teachers with the needed attitude, values, competence, and knowledge to also impart these qualities in their learners. Active-learning activities can take many forms, including constructive and healthy group discussions, think-pair-share, concept mapping, conceptual clicker questions, structured and unstructured problems, or case studies (Handelsman et al., 2007; Allen \& Tanner, 2009). All these activities can involve student interaction, taking advantage of the small-group process in facilitating comprehension and problem solving. Attention should be given to pre-service teachers when they attend to youth out of school experiences in their homes and communities. Therefore, pedagogy at the Colleges of Education should seek to employ the various teaching methods and ICT integration.

\section{CONCLUSION}

The universities should train pre-service teachers to be well vexed in pedagogical content knowledge in the subject area of Integrated Science through the establishment of departments for Integrated Science. To improve on the teaching and learning in science education at the Colleges of Education in Ghana, students with science backgrounds and interest must be admitted pursuing a programme in science education. This must be done to complement the improvement in facilities and equipment with the employment of the various teaching methods and ICT integration needed to increase their content knowledge to practically solve real life problems.

\section{REFERENCES}

Agbidye A, Agbidye G. I., \& Aboho, A. D. (2014). Science Education and the Economic Development of Nigeria. World Educators Forum, 4(1): 2350- 2401.

Aka E. I., Guven E., \& Aydoğdu M. (2010). Effect of problem-solving method on science process skills and academic achievement. Journal of Turkish Science Education, 7(4): 13-25.

Anamuah-Mensah, J. (2004). Enhancing the teaching and learning of science technology for nation building. A report from GAST Annual Conference, Sekondi: Ghana.

Allen, D.E. \& Tanner, K.D. (2009) Transformations: Approaches to College Science Teaching, New York: W. H. Freeman.

Apter D. E. (2008). Ghana's independence: triumph and paradox. https://www.jstor.org/stable/20204242.

Arabacioglu S., \& Unver A. O. (2016). Supporting inquiry based with mobile learning to enhance students' process skills in science education. Journal of Baltic Science Education, 15(2): 216-231.

Azure J. A. (2015). Senior High School students' views on the teaching of Integrated Science in Ghana. Journal of Science Education and Research, 1(2): 49-61.

Barke A., Nyarko S., \& Klecha D. (2011). The stigma of mental illness in Southern Ghana: attitudes of the urban population and patients' views. Social Psychiatry and Psychiatric Epidemiology, 46(11): 11911202.

Bloom, B. (1984) The 2-sigma problem: the search for methods of group instruction as effective as one-to-one tutoring. Educational Research, 13, 4-16.

Brobbey E. W., Baah A., \& Ampon-Wireko S. (2020). Influencing Factors Bedevilling the Study of Science among Ghanaian Students in Senior High Schools. https://www.iiste.org/Journals/index.php/JEP/article/view/52164.

Danso J. B. (2009). Evaluation of inclusive education practice in Ghana: Survey of inclusive pilot schools [Doctoral dissertation, University of Cape Coast].

Demirci Guler M. P. (2013). Success and failure in science education: A focus group study on Turkish students. Journal of Baltic Science Education, 12(6): 716-729.

Gibbs G., \& Simpson C. (2005). Conditions under which assessment supports students' learning. Learning and Teaching in Higher Education, (1): 3-31. 
Godek, Y. (2004). The development of science education in developing countries. The Development of Science Education in Developing Countries. https://www.researchgate.net/publication/253911746.

Handelsman J., Miller S. \& Pfund C. (2007) Scientific Teaching. New York: W. H. Freeman.

Henry R. M. (2017). Engaging participation and promoting active learning through student usage of the internet to create notes for general chemistry in class. Journal of Chemical Education, 94(6): 710-716.

Lepper M.R., \& Woolverton M. (2002) The wisdom of practice: lessons learned from the study of highly effective tutors. Improving Academic Achievement. New York: Academic.

Mickens R., \& Patterson C. (2016). What is Science? Georgia Journal of Science, $74(2 / 3)$. http://digitalcommons.gaacademy.org/gjs/vol74/iss2/3on.

Ministry of Education (MOE), 2019. Science curriculum for primary schoool. Cantoment-Accra:

Mishra S. (2013). Importance of science lab equipment for education. https://EzineArticles.com/expert/San_Mishra/1690861.

O'Oconnor J. P. (2002). Teachers are the problem in SMT, not girls. Retrieved on August 9, 2021 from http://www.adea.org.

Punia T., Jizah O., Adzliana M. D., \& Kamisah O. (2012). Fostering the $21^{\text {st }}$ century skills through scientific literacy and science process skills. Procedia - Social and Behavioral Sciences, 59: 110-116.

Smith M.K., Wood W.B, Krauter K., Knight J.K. (2011) Combining peer discussion with instructor explanation increases student learning from in-class concept questions. CBE Life Sci Education, 1055-63.

Su K.-D. (2016). Strengthening strategic applications of problem-solving skills for Taiwan students' chemistry understanding. Journal of Baltic Science Education, 15(6): 662-679.

University of Texas Arlington (2017). Importance of Science Education in Schools.https://academicpartnerships.uta.edu/articles/education/impor tance-of-science-education.aspx.

Wood C. (2006). The development of creative problem solving in chemistry. Chemistry Education Research and Practice, 7(2): 96-113.

Živkovic S. (2016). A model of critical thinking as an important attribute for success in the 21st century. Procedia - Social and Behavioral Sciences, 232: $102-108$. 